\title{
Knowledge of family members on the rights of individuals affected by mental illness
}

\author{
Familiares de pessoas portadoras de transtorno \\ mental: conhecimento dos direitos à saúde
}

Familiares de personas con trastorno mental:

conocimiento de los derechos a la salud

\author{
Vania Moreno ${ }^{a}$ \\ Guilherme Correa Barbosab
}

DOl: $\quad$ http://dx.doi.org/10.1590/1983-

1447.2015.01.47915

\footnotetext{
a Nurse. Doctor of Nursing. Assistant Professor in the Department of Nursing of the Botucatu School of Medicine, São Paulo State University (Unesp), São Paulo, Brazil.

${ }^{b}$ Nurse. Doctor of Science. Assistant Professor in the Department of Nursing of the Botucatu School of Medicine, São Paulo State University (Unesp), São Paulo, Brazil.
}

\section{ABSTRACT}

The objective of this investigation was to understand what family members know about the rights of individuals affected by mental illness. To this end, a qualitative exploratory study was conducted. A semi-structured interview was used for data collection. Eighteen family members were interviewed at a psychosocial care center (CAPS) and a civil society organization (CSO) located in a municipality in the state of São Paulo, Brazil, between March and September 2013. Data were analyzed using thematic content analysis and the following categories were constructed: mental health services and the rights of individuals affected by mental illness. We were able to infer that in addition to drug-based therapy, mental health services must provide therapeutic activities. Family members of those affected by mental illness were unaware of the Brazilian Psychiatric Reform Law and mentioned the following rights: welfare benefits, free public transport, basic food basket and medications.

Keywords: Health legislation. Mental health services. Patient rights.

\section{RESUMO}

0 objetivo desta investigação foi compreender o que os familiares conhecem a respeito dos direitos das pessoas portadoras de transtorno mental. Foi realizada uma investigação exploratória de cunho qualitativo. Como instrumento de coleta de dados, foi realizada uma entrevista semiestruturada. Foram entrevistados 18 familiares de um centro de atenção psicossocial e de uma associação civil localizados em município do interior do estado de São Paulo, Brasil, no período de março a setembro de 2013. Para análise de dados, utilizou-se a análise de conteúdo, vertente temática, e foram construídas as seguintes categorias: os serviços de saúde mental e os direitos da pessoa portadora de transtorno mental. Pode-se inferir que, além do tratamento medicamentoso, os serviços de saúde mental deveriam ofertar atividades terapêuticas. Os familiares das pessoas portadoras de transtorno mental desconheciam a lei da Reforma Psiquiátrica e mencionaram como direitos: benefício, gratuidade no transporte coletivo, cesta básica e medicação gratuita.

Palavras-chave: Legislação sanitária. Serviç̧os de saúde mental. Direitos do paciente.

\section{RESUMEN}

El objetivo de esta investigación fue entender lo que los familiares saben sobre los derechos de las personas con trastornos mentales. Se realizó una investigación exploratoria de naturaleza cualitativa. Como instrumento de recolección de datos, se utilizó una entrevista semiestructurada. Entrevistamos a 18 familiares de un centro de atención psicosocial y una asociación civil que asisten a los enfermos mentales, ciudad del estado de São Paulo, Brasil, de marzo a septiembre de 2013. Para el análisis de los datos, se utilizó el análisis de contenido, parte temática, y se construyeron las siguientes categorías: servicios de salud mental y los derechos de las personas con trastorno mental. Se puede inferir que, además del tratamiento con drogas, los servicios de salud mental deben ofrecer actividades terapéuticas. Los familiares de las personas con trastornos mentales no son conscientes de la ley de la Reforma Psiquiátrica, y mencionaran los siguientes derechos: beneficio, la gratuidad en el transporte público, los alimentos básicos y medicamentos gratuitos.

Palabras clave: Legislación sanitaria. Servicios de salud mental. Derechos del paciente. 


\section{DINTRODUCTION}

The fight for the rights of people with mental illness has been a matter of constant discussion since the advent of the Brazilian Psychiatric Reform. To visualize the construction of such rights, the present study consulted the current legislation and the final reports that were produced at the Brazilian national conferences on mental health.

The conferences are spaces open to the public for collective deliberation on the directives that should guide the Brazilian Unified Health System (SUS, as per its acronym in Portuguese). The final reports are documents aimed at disseminating the deliberations made at the conferences to the general public(1). Such reports intend to foster the creation of directives for the routine of mental health services and instigate debates among service users, family members and health professionals.

The I National Conference on Mental Health, held in 1987, was an unfolding of the VIII Healthcare Conference and was organized around three basic themes. The first touched on economy, society and state: impacts on health and mental illness; the second discussed the topic of healthcare reform and the reorganization of mental health care; and the third point dealt with citizenship and mental illness: the rights, duties and legislation of individuals with mental illness ${ }^{(2)}$.

The first legislative movement related to guaranteeing the rights of people with mental illness happened in 1989 with deputy Paulo Delgado. He presented Bill no. 3.657 to the Chamber of Deputies, which provided for the redirecting of the current care model by prohibiting the construction of new psychiatric hospitals, incentivizing the progressive replacement of existing hospital beds, and regulating involuntary commitment. Thus, the bill introduced the legal framework that would serve as a forum for reviewing psychiatric hospitalization and as an instrument for guaranteeing civil rights ${ }^{(3)}$.

In 1992, the II National Conference on Mental Health was held in the city of Brasilia under the theme "Restructuring mental health care in Brazil: the health care model and the right to citizenship." The final report produced at this conference indicated two conceptual frameworks: comprehensive care and citizenship. The connection between citizenship and health was made explicit, becoming the guiding principle for the new model to be construct$\mathrm{ed}^{(4)}$. The final report deliberated that from thereon, family members had the right to access information contained in patient records and to information on the patient's clinical condition, prognosis and treatment. Another victory for family members was the possibility of making daily visits to hospitalized patients ${ }^{(5)}$.
The period between 1992 and 2001 was marked by the expansion of the psychosocial care network. To this end, psychosocial care nuclei (NAPS), psychosocial care centers (CAPS), and other psychosocial care facilities were implemented all over Brazil.

In April 2001, after 12 years under evaluation by the Brazilian National Congress and without unanimous approval of the idealizers of the Psychiatric Reform ${ }^{(4)}$. Law no. 10,216 was sanctioned, ensuring the protection and rights of individuals affected by mental illness and redirecting the mental health care model. Article 1 of the law covers the topic of human rights and article 2 ensures that patients and family members be officially informed of the rights of people with mental illness on receiving any form of mental health care treatment. Any patient has: 1) the right to the best treatment available in the healthcare system in accordance with the needs of each individual; 2 ) the right to humane and respectful treatment; 3) the right to be protected against abuse and exploitation; 4) the right to guaranteed confidentiality of all information provided; 5) the right to a physician; 6) the right to free access to all available forms of communication; 7) the right to information on one's own illness and treatment; and 8) the right to be treated in a therapeutic environment, preferably in community-based services ${ }^{(3)}$.

Law 10.216/01 allowed for the regulation of psychiatric hospitalization and implemented a safety mechanism for protecting the rights of people with mental illness ${ }^{(6)}$.

Since the enactment of the Psychiatric Reform Law, the Brazilian Ministry of Health has produced ordinances that provide the necessary instruction for complying with the law. Such ordinances establish directives and norms for mental health services and give special attention to the family who should be part of the therapeutic plan during hospitalization, in accordance with its needs and those of the patient. The ordinances also ensure that family and patients be informed about the illness and its treatment, in a therapeutic environment, preferably in community-based services ${ }^{(7)}$. Furthermore, Ordinance 336/2002 determines that family care must be contemplated as part of the actions developed by the CAPS(8).

In December 2001, the III National Conference on Mental Health was held, under the theme "Yes to care, no to exclusion: Implementing the Psychiatric Reform with access, quality, humanization and social control." At this conference, two specific points were made with respect to family members. The first point proposed the empowerment of family members with respect to the legislation, decrees and ordinances that regulate mental health care. The second stated that healthcare services must guarantee the 
preservation of family ties through family support groups, and through information that helps them understand the process of illness and how to deal with people with mental illness and prepare for social coexistence ${ }^{(8)}$.

In 2010, the IV Conference on Mental Health - Intersectorial was held. Recommendations regarding the role of family pointed to the need to create means for raising public awareness on the importance of family participation throughout the treatment process. It is up to the CAPS teams and other mental health units to foster active and permanent dialogue with families so as to contribute to mental health services. It is also their responsibility to stimulate the exchange of information to mobilize families in the search of ensuring the civil rights and responsibilities of those affected by mental illness ${ }^{(9)}$.

The family can be thought of as a cultural healthcare system, as its members possess a set of explanatory elements of the health-illness process. Furthermore, its actions are aimed at health promotion, prevention and treatment by using a set of values, beliefs, knowledge and practices that are shared and resignified through social interaction and in the social and cultural environment ${ }^{(10)}$. When invited to be a part of the care scenario, the family allows for health needs to be transformed into demands for mental health services as well as into public policies(11).

We emphasize that when the state considers families to be the main responsible entity for the wellbeing of its members, it adopts what is called the familial view. According to this understanding, the family occupies a central caring and protective role and the state conducts temporary interventions when the family's protection mechanisms falter ${ }^{(11)}$.

Under the protective tendency, the guarantees set forth in public policies serve to strengthen the family's capacity to provide care and protection to its members, as it can become vulnerable due to transformation within itself and in society ${ }^{(11)}$.

Thus, the family has now become a part of the Psychiatric Reform social movement; nonetheless, what do families know about the legislation that seeks to ensure the rights of individuals with mental illness? To answer this question, the objective of the present study was to investigate what family members know about the rights of those affected by mental illness, both in the case of hospitalization and of integration into local outpatient services and the community.

\section{$\square$ METHOD}

This was an exploratory and descriptive study of quantitative nature conducted with family members of patients treated in two locations. The first was a psychosocial care center that provides intensive care to individuals with mental illness. The second location was a non-profit civil society organization (CSO) that develops actions to support individuals with mental illness and aid their reintegration into the family and the community, in defense of their rights. Both facilities are located in the state of São Paulo, Brazil.

The CAPS and CSO teams selected the family members that would participate in the study. Family members of patients with at least six months of participation in events at these facilities were included. All family members of individuals who had been participating for less than six months were excluded from the study.

Interviews were scheduled ahead of time at the CAPS and CSO and conducted individually between March and September 2013. All interviews were recorded on an audio device. Participants were given a questionnaire to collect sociodemographic data such as gender, age, education level, marital status and place of work. A semi-structured interview was conducted with the following guiding questions: What do you know about the psychiatric reform? Are you familiar with the rights of individuals with mental illness? Which ones? Where did you get this information? Could you cite the current legislation?

Content analysis was used to analyze data. This technique aims to describe the content in messages ${ }^{(12)}$.

After their completion, interviews were transcribed and then analyzed individually so as to identify relevant patterns. At a later moment, thematic analysis was conducted by organizing the content in order to compare different answers and create the groups of meaning that make up the communication and its meaning through words, phrases or themes that were relevant to the object of study ${ }^{(12)}$. Finally, the following empirical categories were constructed: mental health services and the rights of individuals affected by mental illness.

The study was approved by the research ethics committee of the Botucatu School of Medicine under protocol CEP - 3079-2009.

\section{— RESULTS AND DISCUSSION}

Eighteen family members were interviewed for this investigation. Age of participants ranged from 48 to 74 years; 16 family members were female and 2, male. Most participants were the patients' mothers, followed by sisters, father and spouse. Education level varied from illiteracy to complete higher education. Two participants were formally employed and the others were either retired, unemployed or not formally employed. 


\section{Mental health services}

Mental health services were still seen by family members as places of care where people with mental illness receive medication for their disorder:

Yes, we come here to get the medicine, but we don't do anything here. It started well, but now we don't do anything, we come and loaf around, we come to get the medicine (I3).

I think the medicine is a good thing, because it's expensive, in this sense it's a good thing, but I don't know if the medical part is all that good (14).

He wouldn't accept the medication. It was a struggle. After coming to the CAPS III, we got a place in the day hospital. That was good. Today he takes his medicine on his own, he knows what he has, he's doing well, but he is not a normal person (I13).

However, participants mentioned that the CAPS should be a space that not only provides medication, but also conducts other activities. Studies have shown that treatment at substitute and out-of-hospital care services should offer therapeutic activities as a field of possibilities, with the goal of fostering the autonomy of individuals with mental illness and of their families. Nonetheless, the authors recognize that the care provided converges only with regards to medical knowledge and the medicalization of symptoms ${ }^{(13-14)}$.

Drug-based treatment should not be the main recourse used by mental health services. Instead, overlapped knowledge from different fields should be used to build social networks in which individuals with mental illness and their families could be inserted ${ }^{(15)}$. Nonetheless, family members play an active role when dealing with mental health services:

I look for whoever it is I have to look for. I don't even know if I'll encounter difficulties anymore. The services are smart about me now. They treat me well and all. They are afraid I will report them. I filed a complaint against the CAPS II once. They want to talk about the service but they don't even have a core team (113).

A study indicated that families of individuals affected by mental illness are allies in the process of psychosocial rehabilitation as a form of promoting social reintegration, taking into account the personal, social and political dimensions that involve their daily life ${ }^{(16)}$.

\section{The rights of individuals affected by mental illness}

The families who went after the rights of their members with mental illness did so with the help of a professional who mediated their interests and also provided orientation about what action to take:

I had to find a lawyer to get the help and medication he needs (110).

(...) I had to hire a lawyer and from there I became familiar with the rights, learning how I could solve our situation within the law (114).

The families that delegated the search for the rights of those with mental illness to lawyers were not familiar with the Psychiatric Reform Law that guarantees humane and respectful treatment to individuals affected by mental illness in item two of its sole paragraph. Such treatment must be in the exclusive interest of benefitting patient health and achieving recovery through reintegration into the family, work, and the community environment ${ }^{(7)}$. Family members mentioned the following rights:

He gets money and medicine. When he came to live with me, I started taking him to the psychiatrist and the psychiatrist told me about this place. Then you people told me about the welfare benefit and SUS. I was able to get him treatment through SUS and we got the benefit (118).

I learned that I have the right to a basic food basket every month because she is being treated here through the mother of one of the patients here, she's a family representative. But it was only because of her, I would've never imagined such a thing (I3).

Look, what I know is that they have the right to free public transport, to medication, and nowadays they can't be committed like they used to be. That I know. What my daughter went through, the younger ones cannot go through. Services have to take good care of them, they can't mistreat them, they have to explain what is going on (115).

Some rights mentioned by families included welfare benefits received to help with household expenses, such as free medication, free public transport and the basic food basket. The familial view present in their discourse conceives such benefits as temporary forms of guaranteeing 
the protection of their members, as public policies are a form of compensating for when families are not able to develop adequate survival and coexistence strategies by working together with solidarity networks ${ }^{(11)}$.

This study observed that the health services in question did not base their practices on the bioethics that defends that social inclusion should occur as a part of the routine of such services. This process is aided by actual people who take into account the political dimension of inclusion and who aim to achieve the empowerment, freedom and emancipation of these social subjects ${ }^{(17)}$, all directives that were set forth by mental health conferences.

The discourse of the families at the civil society organization demonstrated that they take ownership of the rights related to the care of individuals with mental illness and of the possibility of disseminating such information:

At the health service, nobody knows anything, and if they do, they are never available to talk. Everything I learned came from seeking out the judicial system. I participate in events related to mental health as well. And at the Health Council, I represent patients. I like to know about this, but I never got any information at the services. My children have health insurance and we don't use the CAPS. I think the people who work there don't know everything I know (112).

Here, I came in contact with other mothers who suffered like me. But I also participate in all the talks, discussion groups and whatever else there is about mental health. In these spaces, we come to learn a lot and we are able to pursue our interests. Or at the very least, if we have the information, we have to divulge it (113).

Community services...I think that this is the only healthy place for discussing and activating Social Movements. The location is good, the staff is young and identify with our cause. They fight with us. Community services do not have such availability (114).

Families reported that professionals in mental health services did not promote a space for learning about the rights of those affected by mental illness. Instead, their care practice consisted of technical and scientific aspects alone. Thus, families sought out the association as a form of sharing with others who had undergone similar experiences the suffering that comes when one of its members suffers from mental illness, as they needed the emotional support and assistance to be able to care for them ${ }^{(18-19)}$.

By participating in the CSO, family members displayed their ability to care for and protect their members, as guar- anteed by public policies. Due to their social vulnerability, families of individuals with mental illness should be recognized as an entity that deserves constant state protection, not just specific and sporadic interventions ${ }^{(11)}$.

The family members in this study did not mention the Psychiatric Reform Law. This finding can indicate that in the fight for the rights of those with mental illness, everyday needs such as transportation, food and medication take priority over the issues provided for by the Law.

\section{EINAL CONSIDERATIONS}

The interviewed family members were aware of rights related to medication, transportation and the basic food basket. However, they were not familiar with those regarding hospital treatment and commitment and their actual participation. This was also the case with respect to non-asylum care services.

The present study investigated two mental health facilities and demonstrated that family members have scarce knowledge on mental health rights, which can be considered a limitation of the investigation. Therefore, mental health professionals must consider this fact and act in the sense of establishing a space that encompasses not only health care, but also political aspects of such care, while the process of constructing the rights of mental health patients takes place. In other words, broadening this discussion should be an implicit part of psychosocial care.

Families are allies in the care process and thus need information to fight for the best possible quality of life for those with mental illness. Such information is available at the Conferences on Mental Health and in the Psychiatric Reform Law. The joint effort of mental health professionals and family members represents hope for the construction of these "new subjects of law."

\section{REFERENCES}

1. Guizardi FL, Pinheiro R, Mattos RA, Santana AD, Matta G, Gomes MCPA. Participação da comunidade em espaços públicos de saúde: uma análise das Conferências Nacionais de Saúde. Physis. 2004;14(1):15-39.

2. Ministério da Saúde (BR). Relatório final da I Conferência Nacional de Saúde Mental; 1987 jun 25-28; Brasília. Brasília: Ministério da Saúde; 1988. 43 p.

3. Amarante P. Saúde mental, desinstitucionalização e novas estratégias de cuidado. In: Giovanella L, Escorel S, Lobato LVC, Noronha JC, Carvalho Al, organizadores. Políticas e sistema de saúde no Brasil. Rio de Janeiro: Editora Fiocruz; 2008. p.735-60.

4. Pereira RC. Políticas de saúde mental no Brasil: o processo de formulação da lei de reforma psiquiátrica (10.216/01) [tese]. Rio de Janeiro: Escola Nacional de Saúde Pública, Fundação Oswaldo Cruz; 2004. 
5. Ministério da Saúde (BR). Relatório final da II Conferência Nacional de Saúde Mental; 1992 dez 1-4; Brasília. Brasília: Ministério da Saúde; 1994. 63p.

6. Britto RC. A internação psiquiátrica involuntária e a Lei 10.216/01: reflexões acerca da garantia de proteção aos direitos da pessoa com transtorno mental [dissertação]. Rio de Janeiro: Escola Nacional de Saúde Pública, Fundação Oswaldo Cruz; 2004.

7. Ministério da Saúde (BR). Secretaria de Atenção à Saúde. Legislação em saúde mental: 1990-2004. Brasília: Ministério da Saúde; 2004.

8. Ministério da Saúde (BR). Sistema Único de Saúde. Conselho Nacional de Saúde. Relatório Final da III Conferência Nacional de Saúde Mental. Brasília: Conselho Nacional de Saúde, Ministério da Saúde; 2002. 213 p.

9. Ministério da Saúde (BR). Relatório final da IV Conferência Nacional de Saúde Mental - Intersetorial; 2010 jun 27-jul 01, Brasília. Brasília: Conselho Nacional de Saúde; 2010. 210p.

10. Elsen I. Cuidado familial: uma proposta inicial de sistematização conceitual. In: Elsen I, Marcon, SS, Silva MRS, organizadoras. 0 viver em família e sua interface com a saúde e a doença. Maringá: Eduem; 2004. p.19-28.

11. Mioto RCT. A família como referência nas políticas públicas: dilemas e tendências. In: Trad LAB, organizadora. Família contemporânea e saúde: significados, práticas e políticas públicas. Rio de Janeiro: Editora Fiocruz; 2010. p.51-66.
12. Bardin L. Analise de conteúdo. Lisboa: Edições 70; 2006. 223p.

13. Fiorati RC, Saeki, T. As dificuldades na construção do modo de atenção psicossocial em serviços extra-hospitalares em saúde mental. Saúde em debate 2013; 37(97):305-12.

14. Bessa JB, Waidman MAP. Família da pessoa com transtorno mental e suas necessidades na assistência psiquiátrica. Texto Contexto Enferm. 2013; 22(1):61-70

15. Dimenstein M, Sales AL, Galvão E, Severo AK. Estratégia da atenção psicossocial e a participação da família no cuidado em saúde mental. Physis. 2010;20(4):1209-26.

16. Mielke FB, Kohlrausch E, Olschowsky A, Scheneider JF. A inclusão da família na atenção psicossocial: uma reflexão. Rev Eletr Enferm. 2010;12(4):761-5.

17. Garrafa V. Da bioética de princípios a uma bioética interventiva. Bioética. 2005;13(1):125-34.

18. Almeida KS, Dimenstein M, Severo AK. Empoderamento e atenção psicossocial: notas sobre uma associação de saúde mental. Interface (Botucatu). 2010;14(14):577-89.

19. Brischiliari A, Bessa JB, Waidman MAP, Marcon SS. Concepção de familiares de pessoas com transtorno mental sobre os grupos de autoajuda. Rev Gaucha Enferm. 2014;35(3):29-35.
Author's address:

Vania Moreno

Rua Miguel Catarino, 481, Jardim Panorama

18608-210, Botucatu, SP

E-mail: btmoreno@terra.com.br
Received: 13.06.2014

Approved: 12.02.2015 